\title{
Editorial \\ Aftertreatment DeNOx Systems for Future Light Duty Lean-Burned Emission Regulations
}

\author{
Beñat Pereda-Ayo and Juan Ramon González-Velasco *
}

check for updates

Citation: Pereda-Ayo, B.;

González-Velasco, J.R. Aftertreatment DeNOx Systems for Future Light Duty Lean-Burned Emission Regulations. Catalysts 2021, 11, 188 . https://doi.org/10.3390/catal 11020188

Academic Editor: Jean-François Lamonier

Received: 25 January 2021

Accepted: 25 January 2021

Published: 1 February 2021

Publisher's Note: MDPI stays neutral with regard to jurisdictional claims in published maps and institutional affiliations.

Copyright: (c) 2021 by the authors. Licensee MDPI, Basel, Switzerland. This article is an open access article distributed under the terms and conditions of the Creative Commons Attribution (CC BY) license (https:/ / creativecommons.org/licenses/by/ $4.0 /)$.
Department of Chemical Engineering, Faculty of Science and Technology, Universidad del País Vasco UPV/EHU, Barrio Sarriena s/n, 48940 Leioa, Spain; benat.pereda@ehu.es

* Correspondence: juanra.gonzalezvelasco@ehu.eus

Future light duty vehicles in Europe and the United States are required to be certified, owing to progressively more and more stringent regulations. Improving the exhaust aftertreatment systems must be considered as an integral part of the 21st century vehicle development process. The current potential technologies for NOx removal, namely, NOx storage and reduction (NSR) and selective catalytic reduction (SCR), present some limitations and uncertainties for extensive application in light-duty automobiles (Reference [1], Table 3). The cold phase during the startup of the engine is now heavily weighted, and improving the efficiency of the catalyst during this phase is crucial to meeting the low tailpipe emission targets. The combination of LNT with SCR catalysts is an open strategy for expanding the temperature window for efficient operation and lowering precious metals loads [1].

This Special Issue collects two reviews and four original research papers focused on the challenges for a new generation of DeNOx catalysts. Diverse aspects on surface chemistry and physics for high efficiency, low-temperature catalysis and after-treatment architectures with low cost, high NOx removal efficiency, and long durability to meet the ever rigorous NOx emission are proposed, with the aim of revealing promising signs that NOx can be reduced significantly below current standards.

The selective catalytic reduction promotes NOx removal with an externally added reducing agent such as $\mathrm{NH}_{3}\left(\mathrm{NH}_{3}-\mathrm{SCR}\right)$. Ammonia is produced upon thermal decomposition of urea-water solution (UWS), which is stored on-board. Urea is injected in the engine exhaust tail-pipe and needs to be homogeneously mixed with the gas stream to boost NOx removal. The development of compact SCR units located close to the engine, offer a huge potential for NOx reduction due to higher exhaust temperature and lower warm-up time. However, the close-coupled configuration reduces the available distance for mixing the urea. Hence, the properties of the urea-water solution spray become particularly critical for enhancing NOx elimination. There are two papers of this special issue devoted to study the injection and mixing of the urea-water solution [2,3]. Kapusta et al. [2] have studied the flow characteristics and have determined the global and local spray parameters for the urea-water solution compared to pure water. They observed differences in almost all considered spray parameters for urea-water solutions with respect to pure water. Thus, the importance of precisely determining the spray parameters of urea-water solutions was highlighted for obtaining reliable results by CFD simulations. On the other hand, Qian et al. [3] focused their study on the design of the urea-water solution nozzle. Using CFD simulation, they proposed and optimized nozzle design that can increase the uniformity of the $\mathrm{NH}_{3}$ distribution at the inlet face of the SCR from 0.58 (for the standard design) to 0.92 . Besides, the optimized design reduced significantly deposit formation at low temperature $\left(250{ }^{\circ} \mathrm{C}\right)$, due to faster urea pyrolysis rate.

The research progress in the last 20 years related to the utilization of $\mathrm{WO}_{3}-\mathrm{V}_{2} \mathrm{O}_{5}$ based materials as SCR catalyst is reviewed by Zhang et al. [4]. To date, $\mathrm{WO}_{3}-\mathrm{V}_{2} \mathrm{O}_{5} / \mathrm{TiO}_{2}$ catalysts are the most effective systems to reduce $\mathrm{NOx}$ by $\mathrm{NH}_{3}-\mathrm{SCR}$ in large-scale transport 
facilities. Therefore, the effect of $\mathrm{WO}_{3}$ and $\mathrm{V}_{2} \mathrm{O}_{5}$ on the catalytic performance must be understood for further research in this area. The effect of the preparation method on the activity and selectivity is first analyzed. Then, attention is paid to the chemical composition of the catalyst. In this section, the role of the support and the addition of doping elements or promoters is studied. Finally, the main deactivation causes are analyzed. Besides, the influence of $\mathrm{SO}_{2}$ and $\mathrm{H}_{2} \mathrm{O}$ in the reaction mixture is addressed.

Lean NOx trap (LNT), or NOx storage and reduction (NSR) technology is an effective strategy able to attain high NOx conversions over a wide range of temperatures without the need of additional on-board reductants. One of the main drawbacks for the practical application of NSR technology is its susceptibility to sulfur poisoning. The as-formed sulfates onto the basic storage sites limit the ability of the catalyst to store NOx. Periodic high temperature excursions are needed to decompose sulfates, leading to higher fuel consumption and catalyst aging. De Abreu Goes et al. [5] analyze the sulfur poisoning effects on modern Lean NOx Traps. $\mathrm{Al}_{2} \mathrm{O}_{3}, \mathrm{Mg} / \mathrm{Al}_{2} \mathrm{O}_{3}$, and $\mathrm{Mg} / \mathrm{Ce} / \mathrm{Al}_{2} \mathrm{O}_{3}$ mixed with Pt, $\mathrm{Pd}$, and $\mathrm{Pt}-\mathrm{Pd}$ were used as model catalytic compounds. Micro-flow reactor tests together with DRIFTS was employed to investigate the stability of sulfates. It was observed that the addition of $\mathrm{Pd}$ and $\mathrm{Mg}$ into the catalyst formulation can improve the desulfation behavior and reduce the temperature at which sulfates are decomposed.

LNT formulation requires high loadings of noble metals to achieve high NOx removal efficiency, which increases the cost. Recently, perovskites-type oxides $\left(\mathrm{ABO}_{3}\right)$ have emerged as alternative to noble metal based formulations. In fact, Onrubia-Calvo et al. [6] present the perovskite-based catalysts as efficient, durable and economical LNT formulation. The activity of the perovskite-based materials is reviewed as a function of the synthesis method and chemical composition. Specifically, the activity of $\mathrm{LaCoO}_{3}$ and $\mathrm{LaMnO}_{3}$ perovskites doped with strontium is compared to model Pt-based LNT formulation for the oxidation of $\mathrm{NO}$ to $\mathrm{NO}_{2}$, which is considered a primary step for NOx adsorption. The oxidation ability of the perovskites greatly exceeds that of Pt-based LNT formulation. Finally, the effect of the inclusion of $\mathrm{SO}_{2}$ and $\mathrm{H}_{2} \mathrm{O}$ in the feed is analyzed.

The combination of a close-coupled LNT and downstream SCR catalysts is considered crucial to meet the forthcoming NOx emission regulations. The concept of coupling LNT with SCR is based on producing a controlled amount of $\mathrm{NH}_{3}$ in the LNT, which is stored on the downstream SCR catalyst to reduce the remaining NOx. Cortés-Reyes et al. [7] present a combined LNT-SCR system for DeNOxing in the presence of $\mathrm{CO}_{2}$ and $\mathrm{H}_{2} \mathrm{O}$. $\mathrm{Pt}-\mathrm{Ba}-\mathrm{K} / \mathrm{Al}_{2} \mathrm{O}_{3}$ is used as LNT and small pore size zeolite SAPO- 34 with $2 \% \mathrm{Cu}$ inside the structure as SCR. The lean-rich phase time ratio and $\mathrm{H}_{2}$ concentration is together analyzed to construct operational maps and determine the optimum operating conditions. Onrubia-Calvo et al. [6] also used perovskite based LNT formulation in combination with $4 \% \mathrm{Cu}-\mathrm{SAPO}-34$ for enhancing NOx removal. They confirmed that $\mathrm{NOx}$ and $\mathrm{NH}_{3}$ conversion are significantly enhanced for the combined NSR-SCR while maintaining high $\mathrm{N}_{2}$ selectivity.

Author Contributions: Both authors contribute equally. All authors have read and agreed to the published version of the manuscript.

Funding: This research was funded by the Basque Government (Project IT1297-19).

Data Availability Statement: No new data were created in this editorial. Referred papers are open access in https://www.mdpi.com/journal/catalysts/special_issues/DeNOx_Systems_NSR_SCR.

Conflicts of Interest: The authors declare no conflict of interest.

\section{References}

1. González-Velasco, J.R.; Pereda-Ayo, B.; De-La-Torre, U.; Urrutxua, M.; López-Fonseca, R. NOx storage and reduction coupled with selective catalytic reduction for NOx removal in light-duty vehicles. ChemCatChem 2018, 19, 2928.

2. Kapusta, L.J.; Sutkowski, M.; Rogóz, R.; Zommara, M.; Teodorczyk, A. Characteristics of Water and Urea-Water Solution Sprays. Catalysts 2019, 9, 750. [CrossRef] 
3. Qian, F.; Ma, D.; Zhu, N.; Li, P.; Xu, X. Research on Optimization Design of SCR Nozzle for National VI Heavy Duty Diesel Engine. Catalysts 2019, 9, 452. [CrossRef]

4. Zhang, W.; Qi, S.; Pantaleo, G.; Liotta, L.F. $\mathrm{WO}_{3}-\mathrm{V}_{2} \mathrm{O}_{5}$ Active Oxides for NOx SCR by $\mathrm{NH}_{3}$ : Preparation Methods, Catalysts' Composition, and Deactivation Mechanism-A Review. Catalysts 2019, 9, 527. [CrossRef]

5. De Abreu Goes, J.E.; Kristoffersson, A.; Olsson, L. Sulfur Poisoning Effects on Modern Lean NOx Trap Catalysts Components. Catalysts 2019, 9, 492. [CrossRef]

6. Onrubia-Calvo, J.A.; Pereda-Ayo, B.; González-Velasco, J.R. Perovskite-Based Catalysts as Efficient, Durable, and Economical NOx Storage and Reduction Systems. Catalysts 2020, 10, 208. [CrossRef]

7. Cortés-Reyes, M.; Herrera, C.; Larrubia, M.A.; Alemany, L.J. Hybrid Technology for DeNOxing by LNT-SCR System for Efficient Diesel Emission Control: Influence of Operation Parameters in $\mathrm{H}_{2} \mathrm{O}+\mathrm{CO}_{2}$ Atmosphere. Catalysts 2020, 10, 228. [CrossRef] 